DOI

\title{
ОСОБЛИВОСТІ ВИКЛАДАННЯ КУРСУ ЗА ВИБОРОМ “ОСНОВИ КЛІНІЧНОГО МИСЛЕННЯ” НА КАФЕДРІ ПРОПЕДЕВТИКИ ВНУТРІШНЬОЇ МЕДИЦИНИ
}

Н. В. Зозуляк

\author{
ДВНЗ “Івано-Франківський національний медичний університет”
}

\author{
FEATURES OF TEACHING OF THE ELECTIVE COURSE \\ “FUNDAMENTALS OF CLINICAL THINKING” IN THE PROPEDEUTICS \\ OF INTERNAL MEDICINE DEPARTMENT
}

\author{
N. V. Zozuliak
}

\section{SHEI “Ivano-Frankivsk National Medical University”}

\begin{abstract}
На початку третього курсу студентам надається можливість обрати курс за вибором “Основи клінічного мислення”. Після опанування елективного курсу студент має оволодіти вмінням опитувати та обстежувати хворого, оцінювати дані додаткових методів обстежень, аналізувати дані за певним алгоритмом та здійснювати диференційну діагностику захворювань. Для кращого засвоєння матеріалу запропоновано використовувати “метод проектів”, що ѓрунтується на самостійній роботі студента. Тобто студент самостійно виконує обстеження хворих та аналіз отриманих даних, а викладач виступає у ролі “спостерігача”. У результаті предмет засвоюється набагато ефективніше, а заняття проходить цікавіше для студентів.
\end{abstract}

At the beginning of the third year of study students have the opportunity to choose an elective course "Fundamentals of clinical thinking”. After finishing of the elective course the student becomes able to interview and examine the patient, assess patient's additional methods of investigations, analyze the data according to the particular algorithm and make differential diagnosis of diseases. For better learning it was offered to use "method of the project" based on independent work. Student independently performs examining of the patients and analyzing the data, and the teacher acts as an "observer". As a result, the subject is learned by students much more efficiently, and classes are interesting for students.

Вступ. Поняття “клінічне мислення” включає в себе багато складових. Воно грунтується на таких факторах, як досвід і навчання, індуктивне й дедуктивне мислення, інтерпретація фактів, а також, часом, і на інтуїції лікаря [1, 2]. Клінічне мислення $є$ важливою складовою, яка $є$ необхідною впродовж практичної діяльності кожного лікаря. Адже з того моменту, коли пацієнт відчиняє двері, розум лікаря починає діагностичну роботу. Починаючи з ходи, манери говорити, виразу обличчя та інших зовнішніх ознак, визначених у хворого, лікарське мислення невпинно рухається, створюючи діагностичну гіпотезу. Саме тому так важливо розвинути у студента навики логічної та послідовної оцінки певного хворого з формуванням найбільш ймовірного діагнозу [3, 4].

Основна частина. Даний курс за вибором студенти мають змогу обрати на початку третього курсу навчання. Система оцінювання здійснюється відповідно до вимог програми дисципліни та Інструкції

(с) Н. В. Зозуляк про систему оцінювання навчальної діяльності студентів при кредитно-модульній системі організації навчального процесу, затвердженої МОЗ України (2005) [5].

Оцінка за модуль визначається як сума оцінок поточної навчальної діяльності (у балах). За поточну навчальну діяльність студент може отримати максимум 200 балів. Ця оцінка вираховується шляхом множення кількості балів, що відповідають максимальній оцінці (20), на кількість тем у модулі (10): 20×10=200. Мінімальна кількість балів, яку може набрати студент при вивченні модуля, вираховується шляхом множення кількості балів, що відповідають мінімальній позитивній оцінці, на кількість тем у модулі: $10 \times 10=100$. Поточний контроль здійснюється відповідно до конкретних цілей на кожному практичному занятті. Оцінка за практичне заняття складається з суми оцінок початкового, основного та заключного етапів (тестовий контроль, вирішення ситуаційного завдання: інтерпретація скарг та даних анамнезу, інтерпретація 
даних фізикального обстеження, аналіз результатів лабораторно-інструментальних досліджень, встановлення ведучого синдрому).

Для успішного засвоєння матеріалу недостатніми є тільки теоретична підготовка студента та її оцінка під час заняття. Саме тому з метою інтенсифікації процесу навчання запропоновано використовувати так званий “метод проектів”. Даний метод грунтується на самостійній роботі студента - індивідуальній, парній або груповій, яку вони виконують протягом певного відрізка часу. Цей підхід органічно поєднується з груповим (соорегаtive learning) підходом до навчання. Метод проектів завжди припускає рішення якоїсь проблеми, яка передбачає, з одного боку, використання різноманітних методів, засобів навчання, а 3 іншого - інтегрування знань, умінь 3 різних областей науки, техніки, технології, творчих областей [6]. Під час проведення заняття студентам представляють певного хворого (залежно від теми) та пропонують виконати опитування та обстеження хворого за певною схемою:

1. Вивчення скарг шляхом клінічного дослідження (збір анамнезу і фізикальне обстеження).

2. Призначення плану діагностичних тестів.

3. Узагальнення клінічних знахідок і оцінка результатів додаткових методів обстеження для розробки можливих варіантів діагнозу.

4. Диференційний діагноз можливих захворювань.

Кожному із студентів пропонується виконувати певну роль у діагностичному процесі: хтось проводить опитування, інший - об'єктивне обстеження і так далі. Закінчується весь процес обговоренням можливих диференційних діагнозів та обгрунтуванням попереднього діагнозу. Таким чином у

\section{Список літератури}

1. Захарченко Т. Роль наочності у процесі викладання професійно орієнтованих дисциплін / Т. Захарченко // Вища школа. - 2013. - № 12. - С. 30-38.

2. Лемешев А. Ф. Клиническое мышление. Врачебная логика как основа методологии диагноза : учеб.-методич. пособие / А. Ф. Лемешев. - Мн. : БГМУ, 2006. - 74 с.

3. Ляшук П. М. Клініка - вища школа лікарської майстерності / П. М. Ляшук, В. П. Пішак // Буковинський медичний вісник. - 2007. - Т. 11, № 1. - С.151-153. студентів виробляються необхідні навики самостійного опрацювання отриманих під час огляду пацієнта даних, а також даних лабораторних та інструментальних методів обстеження. У результаті заняття проходить надзвичайно інтенсивно та $є$ цікавим для студентів, оскільки вони мають змогу виступити у ролі лікаря. Викладач у даному випадку відіграє роль “спостерігача”, який допомагає у разі потреби в процесі обстеження хворого та обговорення діагнозу.

Відповідно до вимог навчального плану елективний курс не передбачає проведення підсумкового модульного контролю. Підсумковий контроль засвоєння дисципліни - семестровий залік. Результати заліку оцінюються за двобальною шкалою: “зараховано”, “не зараховано”. Зараховується дисципліна за умови отримання студентом мінімальної кількості балів - 100 та відсутності невідпрацьованих занять. Для тих студентів, які не отримали мінімум із дисципліни, по завершенню передбачено терміни для відпрацювання та перескладання.

Висновки. Після опанування елективного курсу у студента формуються основи клінічного мислення: він має оволодіти вмінням опитування та обстеження хворого, оцінювати дані лабораторного та інструментального обстеження, інтегрувати свої знання про людину, її органи та системи, здійснювати диференційну діагностику захворювань та, діючи за певним алгоритмом, приймати обгрунтоване рішення. Студент здатен самостійно отримувати інформацію, аналізувати ії та робити логічний висновок. Окрім того, наочність прикладів під час заняття сприяє тому, що отримана інформація засвоюється набагато швидше, а отримані навики залишаються в пам’яті надовго.

4. Ясько Б. А. Психология личности и труда врача : учеб. пос. / Б. А. Ясько. - Ростов н/Д : Феникс, 2005. 250 c.

5. Мілерян В. Є. Методичні основи підготовки та проведення навчальних занять в медичних вузах : метод. посіб. / В. Є. Мілерян. - К., 2006. - 84 с.

6. Матяш Н. В. Проектный метод обучения в системе технологического образования / Н. В. Матяш // Педагогика. - 2000. - № 4. - С.38 - 44. 